\title{
Perceptions of Pre-Service Teachers about Teacher Professional Ethics Course Through Metaphors
}

\author{
Süreyya Genç \\ Correspondence: Süreyya Genç, Assist. Prof. Dr., Faculty of Education, Department of Fine Arts Education, Bartın \\ University, Turkey.
}

Received: January 17, 2019

Accepted: February 11, 2019

Online Published: February 15, 2019

doi:10.11114/jets.v7i3.3977

URL: https://doi.org/10.11114/jets.v7i3.3977

\begin{abstract}
The aim of this study is to determine the perceptions of pre-service teachers towards teacher professional ethics course. The research was carried out with 138 pre-service teachers attending pedagogical formation training certificate program a public university in Turkey. In the study, a phenomenological method was used within the scope of qualitative research model. A semi-structured form with open-ended questions was used as a data collection tool to reveal pre-service teachers' perceptions of teacher professional ethics course. In this form, the pre-service teachers were asked to complete the sentence "the teacher professional ethics course is like ......; because ......". The results obtained from the pre-service teachers' responses were analyzed using content analysis technique. Based on these metaphors and the content analysis, the validity-reliability of the categories were shared with 3 faculty members who specialize in the field of metaphors and category lists. After expert opinions, non-overlapping metaphors were determined and the final shape was given. As a result of the research, it was found out that the pre-service teachers mostly expressed the compass and light metaphors from the metaphors they produced for the teacher professional ethics course. Based on their, "the course guiding students" category is the most commonly expressed metaphor among the categories formed in common characteristics. According to the pre-service teachers, teacher professional ethics course guides people in the right direction. As a result of the research, it was noted that pre-service teachers were able to express their own specific attitude and in-depth thinking abilities to express their perceptions about the subject.
\end{abstract}

Keywords: teacher professional ethics course, pre-service teachers, metaphor, pedagogic formation program

\section{Introduction}

Education is a continuing process, but not a one-time process that has only one purpose and that covers only one period of life. Education is not a result, but is a process that is continuous development. It is important that the change of behavior in the individual must be in the desired direction (Türkeri, 2017: 39). In this sense, the importance of teacher is a common judgment that has been recognized throughout the world for centuries. In the face of the rapid developments in science and technology, the importance of teacher, especially for students, has increased in terms of complicated sensual behaviors to be developed in this world (Ataünal, 2003: 14). According to Ateş (2012: 7), in recent years, the qualified teacher model in people's perceptions has been concentrating on teachers who have advanced field knowledge and who can transmit their knowledge in the best way. Although this perception is partly true, it should be noted that teachers will be a source of inspiration for students and the social environment with the feature of being a model. According to Boon'a (2011: 104) göre; "quality teachers are considered to be those individuals whose pedagogy is grounded in values and beliefs that lead to caring, positive teacher-student relationships, embedded in trust and high standards of professional ethics." According to Pieper (1999), an ideal teacher is not only the person who can teach the best he/she knows but also the person who has become a moral model with his/her lifestyle and behavior. The teacher, who can transform what he teaches into a lifestyle, is an ideal person (Aydın, 2013: 56). In this sense, it is impossible to separate ethics from the concept of teaching.

Ethics in education is of significance because teachers and managers involved in education process are surrounded by moral questions. At the same time, the responsibility of the future generation's education and moral well-being is more than ever over the teachers (Haynes, 2014: 19). Therefore, the teachers of future should consider ethical principles on the basis of their decisions and actions in the face of a situation which they experience. They should be able to develop both a theoretical background and an awareness about how to treat students and others and how to solve ethical dilemmas they might encounter (Aydın, 2013: 56). In one sense teachers are inevitably social and moral educators" (Brady, 2011: 56). 
Teachers have the responsibility to act in the framework of ethical principles, especially with the students involved in their vocational fields and with colleagues by considering responsibilities related to their duties and so on. Teachers who make up the educated social stratum are more responsible for this (Pelit \& Güçer, 2006: 97). Teachers who fulfill their professional skills in the framework of the expected ideals of teaching profession must have the knowledge required by the teaching profession and convert them to skill. To give the pre-service teachers the knowledge and skills required by the professional ethics should be a subject to be emphasized (Erdem \& Simsek, 2013: 198). Teachers who have not been able to internalize ethical behavior, of course, will not contribute to the ethical behavior of their students. To try to pass on the moral values that the teachers do not believe or do not apply in their lives is not expected to be effective on the students. For this reason, it is important that the pre-service teachers get the necessary and adequate training in this regard and should be guided by their occupational ethics (Karataş, 2013: 312). Strike (1990: 47); "among a few of the other authors, is concerned about professional ethics which may be expressed in an ethical code or, more likely, 'is thought of as a product of training'. Thus, he writes for the purpose of considering how professional ethics might best be taught to teachers, and more specifically, 'what a curriculum in professional ethics for teachers in a program of teacher education might be like"” (Bullough, 2011: 24).

In this sense, it is important to educate teachers who directly influence the quality of education that plays an important role in the development of a country. The "professional teaching ethics" course guides the pre-service teachers to be skilled in compliance with ethical principles and to internalize these principles. In the face of the rapid spread and normalization of negative behavior in some countries, it enables pre-service teachers to realize the importance of educating the future generations who will adopt human values. For this reason, determining the perceptions of pre-service teachers for the "teacher professional ethics course" constitutes the purpose of the research. The use of metaphors to determine this perception is considered the most appropriate technique.

Metaphor with many definitions such as figurative expression, trope, simile is defined by Morgan (1998) as a way of thinking and seeing, the concepts that guide our thoughts give direction to our daily activities, to the most ordinary details. What we perceive, the way we find our way around the world, and how we relate to people are built up by our concepts. Therefore, our concept system plays a central role in defining our everyday realities. People often think small things in their daily life almost automatically along certain lines and move accordingly. These lines are in no way clear of what they are literally. The only way to discover is to study languages (Lakoff \& Johnson, 2015: 27-28). "İn a sense metaphors are an artifice, a tool, for opening up possible conceptual territories for exploration, their connections and dynamics in constructing knowledge have inherent limitations. Primarily, a metaphor is not the thing being referred to but a symbol of it" (Yob, 2003: 133). Shuell (1990) explained this power of metaphors as that "if a picture is worth a thousand words, a metaphor is worth a thousand pictures" (Ekici, Baş \& Kizılkaya, 2017). According to Neil Postman (1996: 173-174), metaphor reminds us that poets use metaphors to help us see and feel. Biologists, physicists, linguists and historians, anyone who tries to say something about the world are also same. Metaphor is not ornamental but it is a perception organ. We see the world with metaphors (Arnett, 1999: 80). According to Goldstein (2005), metaphors can be used to identify facts and to encourage re-conceptualizing of problematic situations as they affect how we perceive situations and events (Cerit, 2008: 694). Metaphors have allowed to give depth to literary and verbal richness, as well as, to studies made in the academic dimension and have become increasingly widespread techniques (Koç, 2014: 53).

In our country, there is not a lot of academic research related to metaphors. In a study similar to this study, Gökçek (2018), "Perspectives and solution proposals for teacher profession ethics of pedagogical formation students"; "the results show that students have associated the concept of "ethics" with morality, justice, norm-based rules, and concepts of good-bad, right-wrong, respect-love and equality. Moreover, students emphasized that teachers should obey the ethical principles such as justice, equality, professionalism." In the local literature, there is a general emphasis on professional ethical principles, but there is no research on the perceptions of students for the teaching occupational ethics course. By this study that tried to determine the perceptions of pre-service teachers for teacher professional ethics course through metaphors in the context of pedagogical formation training certificate program.

Teaching bachelor's degree programs of 25 teachers, which have been gradually applied since the 2018-2019 academic year and which have been updated in the composition of the Higher Education Board, focused on pedagogical content education and teaching rather than just transferring pedagogical content. In this context, "Moral values and ethics in education" course became compulsory in the programs to supply professional knowledge and skills related to pedagogical content (Higher Education Board, HEB-a, 2018). The description of the content of this course in all programs is as follows: "Basic concepts and theories about morals and ethics; Ethical principles, ethical rules, business and professional morals/ethics; The profession of teaching in social, cultural, moral, ethical aspects; The right of education and learning, ethical principles in education, teaching, learning and evaluation process; Ethical principles in relations with educational stakeholders (employers/managers, colleagues, parents, professional organizations and society); Education/school administrators, parents and students' moral/ethical responsibilities; Unethical behaviour in 
business and professional life; Ethical regulations concerning public administration, education and teachers in Turkey; Unethical behaviour in school and education, ethical dilemmas, problems and ways of solving; Morals/Ethics education and ethical boards in school; School directors and teachers as a moral/ethical leader" (HEB- b, 2018).

In the basic law of National Education (1973: 5109), the teaching profession is a specialized profession that takes on the duties of teaching, education, and management of the State. Teachers are obliged to perform these duties in accordance with the aims and principles of the Turkish national education. Preparation for teaching profession is provided with general culture, pedagogical content education and pedagogic formation. It is essential to ensure that pre-service teachers receive higher education so that they can acquire the qualifications mentioned above. This education is arranged to allow lateral and vertical transfers at undergraduate and graduate levels. Depending on the procedures and principles determined by the higher education board, the universities give the pedagogical formation program by adhering to the specified procedures and principles. According to the principles and procedures of pedagogic formation training certificate program (2014), the courses in the program were determined. For the students participating in the program, pedagogic content education and instruction-specific courses are arranged in the form of compulsory and elective courses, and course names and hours are determined. According to the procedures and principles of pedagogical formation training certificate program, the teacher professional ethics course, which is the subject of research, is the theoretical elective course of 2 hours. According to the information packages of the universities published on web pages of the universities, the purpose and content of the course is as follows: "The aim of this course is to train pre-service teachers on the concepts related to teacher profession ethics and prepare them for teaching profession as ethical, fair, responsible, helpful, hardworking and compassionate individuals. The content of the course includes examining the factors such as the formation of ethics, professional corruption and the results of unethical behavior in professional life and the concepts of social responsibility etc." (Curriculum and course content, 2018).

In this study, it is aimed to determine the perceptions of pre-service teachers who receive pedagogic formation education from other faculties other than the faculty of education and to follow the effects of the lesson on pre-service teachers. For this purpose that tried to determine what the teacher professional ethics course implies to the students taking pedagogical formation education. The following questions were sought through the metaphors that teacher trainees developed for teaching professional ethics course:

1. What are the metaphors of the pre-service teachers for teacher professional ethics course?

2. Under which categories are metaphors produced by pre-service teachers towards teacher professional ethics course grouped in terms of their common characteristics?

\section{Method}

The research model, study group, data collection tools, data analysis, validity, and reliability are given in this section of the research.

\subsection{Research Model}

This research aims to determine the metaphorical perceptions of the pre-service teachers who were trained in pedagogical formation through the teacher professional ethics course, and the phenomenology method was used as a qualitative research method in the study. According to Bogdan and Biklen (1998: 23), phenomological approach is an approach to understanding the meaning of phenomena and the interaction between people. According to Patton (2014:104), it focuses on how people perceive the phenomenon, how they describe it, how they feel about it, how they understand it, and how they talk about it with others. According to Lester (1999: 2), "the establishment of a good level of rapport and empathy is critical to gaining depth of information, particularly where investigating issues where the participant has a strong personal stake."

\subsection{Study Group}

This research was carried out with the voluntary participation of 138 pre-service teachers who received the teacher professional ethics course within the scope of pedagogical formation education certificate program of the a public university in Turkey in the fall semester of 2018-2019 academic year. Demographic data of the study group are presented in Table 1.

Table 1. Demographic information of the students

\begin{tabular}{lccl}
\hline & \multicolumn{3}{c}{ Pre-service teachers in Pedagogical Formation Education Certificate Program (n=138) } \\
\hline Gender & $\mathbf{n}$ & $\%$ & \multicolumn{1}{c}{ Department } \\
\hline Female & 75 & 54,35 & $\begin{array}{l}\text { History (27), Psychology (1), Mathematics (1), School of Physical Education and Sports -Recreation (5), } \\
\text { Coaching Education (12), Sociology (1), Molecular Biology and Genetics (1), Business Administration (3), } \\
\text { Accounting and Financial (1), Turkish Language and Literacy (22), Child Development and Education (1) }\end{array}$ \\
\hline Male & 63 & 45,65 & $\begin{array}{l}\text { History (15), Recreation (27), Coaching Education (17), Sports Management (1), Economics (1), Turkish } \\
\text { Language and Literacy (2) }\end{array}$ \\
\hline
\end{tabular}




\subsection{Data Collection Tools}

As a data collection tool, the metaphors were utilized. The question sentence prepared for this purpose is "teacher professional ethics course is like...... because......" and the students were asked to complete the gaps. Yıldırım and Şimşek (2013) stated that the question of "why" should be asked because the metaphor alone could not fully uncover the descriptive and visual power. For this reason, the question "why..." was asked them to reveal the meaning of the metaphors they use in the prepared question form. In this way, we would be able to examine the students' perceptions of teacher professional ethics course and the source of these perceptions in depth.

\subsection{Data Analysis}

The data obtained within the scope of the research were evaluated with content analysis technique. The object of (qualitative) content analysis can be all sort of recorded communication (transcripts of interviews, discourses, protocols of observations, video tapes, documents ...). Content analysis analyzes not only the manifest content of the material-as its name may suggest (Mayring, 2000). According to Patton (2014: 453), content analysis is used in general to express any qualitative data reduction and meaning effort attempts to determine basic consistency and meanings based on the volume of qualitative material. In metaphor analysis included in content analysis; there are a number of systematic stages, such as metaphor listing, code issuance, categorization, numbness percentage. This allows us to generate a quantitative data from a qualitative data (Schmitt, 2005).

As a result of the analysis carried out in detailed stages, the descriptive analysis of the metaphors of the students and its sources were made, and the tables were made. In the first stage, answers were examined and unsuitable answer papers were eliminated. The answers of 150 students who participated in the study were examined, and we determined that 12 students were not suitable for the research (because they did not explain of their written metaphors and left it blank), then, these answers were not evaluated. The evaluated papers were numbered from 1 to 138 . The metaphors in the final form of answer papers were re-examined and the categories were developed. The validity and reliability of the categories were determined, the frequencies of metaphors were calculated and presented as tables. At the last stage, data in tables were interpreted. The study also includes direct quotations of students coded as S.1, S.2, S.3, .. to support the relations between metaphors and themes. The Turkish answers of the students are translated into English.

\subsection{Validity and Reliability}

To ensure the validity of the study, the data encoding and data analysis process was thoroughly reported, and the results were explained. In the results section, there are direct quotations from the answers given by the students. According to Gökçe (2006:83), the problem of validity is usually a defining problem in the content analysis. If the definitions of categories are in the form to be shared by everyone, and thus the scale of research measures what it really wants to measure, then no doubt remain about the validity of the research.

To ensure the reliability of the research and to verify the accuracy of the metaphors determined by the researcher and the categories of these metaphors were shared with two faculty members who are experts in the field of study. The experts were asked to match the same metaphors with conceptual categories. Then, the matches made by experts and researchers were compared. Reliability of data analysis was calculated using Miles and Huberman's (1994) formula: Reliability $=$ No. of agreements/(Total no. of agreements+disagreements). As a result of the calculation, the mean reliability of the study was determined as 0,93 . The results of reliability calculations over $70 \%$ are considered reliable (Miles \& Huberman, 1994), therefore, it can be said that data analysis is reliable.

\section{Results}

This section includes the metaphors of the students who received education within the scope of pedagogical formation training certificate program and findings based on the content analysis of the data obtained for the metaphors and their reasons for their teacher professional ethics course.

\subsection{Findings Related to the Metaphors of Pre-Service Teachers for Teacher Professional Ethics Course}

The metaphors stated for the question "teacher professional ethics course is like ..... because ......" by pre-service teachers who participated in the research within the scope of pedagogical education certificate program and who took pedagogical teacher professional ethics course are all positive and shown in Table 2. 
Table 2. Metaphors produced by pre-service teachers towards the teacher professional ethics course

\begin{tabular}{|c|c|c|c|c|c|}
\hline Metaphors & f & $\%$ & Metaphors & $\mathbf{f}$ & $\%$ \\
\hline Tree & 4 & 2.90 & Guide & 8 & 5.80 \\
\hline Family & 3 & 2.17 & Clothes & 1 & 0.72 \\
\hline Hour and minute hand & 1 & 0.72 & Book & 6 & 4.35 \\
\hline Gold & 2 & 1.44 & Coal & 1 & 0.72 \\
\hline Bulb & 1 & 0.72 & User manual & 2 & 1.44 \\
\hline Key & 1 & 0.72 & Hourglass & 1 & 0.72 \\
\hline Basic law & 1 & 0.72 & Polar Star & 1 & 0.72 \\
\hline Encyclopedia & 2 & 1.44 & Library & 2 & 1.44 \\
\hline Moonlight & 1 & 0.72 & Lamp & 2 & 1.44 \\
\hline Mirror & 3 & 2.17 & Writing an article & 1 & 0.72 \\
\hline Father & 1 & 0.72 & Carpentry & 1 & 0.72 \\
\hline Gardener & 2 & 1.44 & Navigation & 2 & 1.44 \\
\hline Building foundation & 1 & 0.72 & Breathing & 1 & 0.72 \\
\hline Cloud & 1 & 0.72 & School & 1 & 0.72 \\
\hline Magnifying glass & 1 & 0.72 & Knitting knot & 1 & 0.72 \\
\hline Answer key & 1 & 0.72 & Guide & 2 & 1.44 \\
\hline Roof & 1 & 0.72 & Guidance Center & 1 & 0.72 \\
\hline Plane-tree & 1 & 0.72 & Wind rose & 1 & 0.72 \\
\hline Flower & 2 & 1.44 & Compass & 9 & 6.52 \\
\hline Flowers shop & 1 & 0.72 & Hour & 2 & 1.44 \\
\hline Child & 2 & 1.44 & Chess & 1 & 0.72 \\
\hline Wave & 1 & 0.72 & Exam & 1 & 0.72 \\
\hline Democracy & 1 & 0.72 & Infinity & 1 & 0.72 \\
\hline Steering wheel & 1 & 0.72 & A road without end & 1 & 0.72 \\
\hline Looking at the Earth Sphere & 1 & 0.72 & Water & 2 & 1.44 \\
\hline Rainbow & 1 & 0.72 & Water, air, soil & 1 & 0.72 \\
\hline Sky & 1 & 0.72 & Pot & 1 & 0.72 \\
\hline Rose & 2 & 1.44 & Scales & 2 & 1.44 \\
\hline Sun & 7 & 5.07 & Seed & 1 & 0.72 \\
\hline Sunlight & 1 & 0.72 & Soil & 2 & 1.44 \\
\hline Glasses & 1 & 0.72 & Salt & 1 & 0.72 \\
\hline Map & 5 & 3.62 & Hope & 1 & 0.72 \\
\hline Tree of Life & 1 & 0.72 & Vitamin & 1 & 0.72 \\
\hline Treasure & 1 & 0.72 & Rain & 1 & 0.72 \\
\hline Sculptor & 1 & 0.72 & Puzzle & 1 & 0.72 \\
\hline Light & 9 & 6.52 & Stuffed grape leaves & 1 & 0.72 \\
\hline Heart & 2 & 1.44 & Star & 1 & 0.72 \\
\hline Turtle & 1 & 0.72 & Time & 1 & 0.72 \\
\hline Captain & 1 & 0.72 & Total & 138 & 100 \\
\hline
\end{tabular}

Table 2 shows that the pre-service teachers who participated in the study produced 77 metaphors related to the teacher professional ethics course. Pre-service teachers mostly produced the light (6.52) and compass (6.52) metaphors. At the same time, it was observed that pre-service teachers expressed their metaphors as guide (5.80), sun (5.07) and book (4.35). After that, the map (3.62) and tree (2.90) metaphors were expressed more than other metaphors.

\subsection{Common Characteristics of the Metaphors}

The categories of the metaphors mentioned in the "teacher professional ethics course is like ..... because ......" expression of pre-service teachers who participated in the research and who took the teacher professional ethics course within the scope of pedagogical formation training certificate program are presented in Table 3. 
Table 3. Categories of the metaphors produced by pre-service teachers for the teacher professional ethics course

\begin{tabular}{|c|c|c|c|}
\hline Category & Metaphors* & $\mathbf{f}$ & $\%$ \\
\hline $\begin{array}{l}\text { A course being an illuminating } \\
\text { factor }\end{array}$ & $\begin{array}{l}\text { Bulb (1), Moonlight (1), Rainbow (1), Sky (1), } \\
\text { Glasses (1), Sun (5), Sunlight (1), Light (8), Lamp } \\
\text { (2) }\end{array}$ & 21 & 15.22 \\
\hline $\begin{array}{l}\text { A course being an information } \\
\text { resource }\end{array}$ & $\begin{array}{l}\text { Encyclopedia (1), Roof (1), Flower shop (1), } \\
\text { Children (1), Rose (1), Guide (1), Book (1), } \\
\text { Hourglass (1), Library (2), Writing an article ( 1), } \\
\text { Clock (1), Puzzle (1) }\end{array}$ & 13 & 9.42 \\
\hline $\begin{array}{l}\text { A course being personal } \\
\text { development resource }\end{array}$ & $\begin{array}{l}\text { Tree (1), Mirror (1), Gardener (2), Child (1), Rose } \\
\text { (1), Hour (1), Infinity (1), Scales (2), Seed (1) }\end{array}$ & 11 & 7.97 \\
\hline An important course & $\begin{array}{l}\text { Tree (1), Hour and minute hand (1), Gold (2), Key } \\
\text { (1), Basic law (1), Father (1), Building foundation } \\
\text { (1), Magnifying glass (1), Flower (1), Democracy } \\
\text { (1), Tree of Life (1), Treasury (1), Heart (1), Turtle } \\
\text { (1), Coal (1), Exam (1), Water (1), A path without } \\
\text { end (1), Earth (1) ), Salt (1), Vitamin (1), Rain (1), } \\
\text { Stuffed grape leaves (1) }\end{array}$ & 24 & 17.39 \\
\hline A course that reminds social values & Tree (1), Family (2), Heart (1), School (1), Star (1) & 6 & 4.35 \\
\hline A course emphasizing vital values & Water (1), Water-air-soil (1), Soil (1) & 3 & 2.17 \\
\hline A developing-forming course & $\begin{array}{l}\text { Tree (1), Mirror (1), Flower (1), Wave (1), Sculptor } \\
\text { (1), Book (1), Carpentry (1), Knitting knot (1), } \\
\text { Chess (1), Pot (1) }\end{array}$ & 10 & 7.25 \\
\hline A course guiding students & $\begin{array}{l}\text { Family (1), Encyclopedia (1), Mirror (1), Cloud (1), } \\
\text { Answer key (1), Plane-tree (1), Steering wheel (1), } \\
\text { Looking at the Earth Sphere (1), Sun (2), Map (5), } \\
\text { Light (1), Captain (1), Guide (7), Clothes (1), Book } \\
\text { (4), User manual (2), Pole star (1), Navigation (2), } \\
\text { Breathing (1) Compass (9), Guide (2), Guidance } \\
\text { center (1), Wind rose (1), Hope (1), }\end{array}$ & 50 & 36.23 \\
\hline
\end{tabular}

* The numbers in parentheses show the frequency of metaphors.

As shown in Table 3, the metaphors stated by the pre-service teachers, who participated in the research, on the teacher professional ethics course were gathered in 8 categories in terms of common characteristics. These categories are as follows; a course being an illuminating factor (15.22), a course being an information resource (9.42), a course being personal development resource (7.97), an important course (17.39), a course emphasizing vital values (2.17), a developing-forming lesson (7.25) and a course guiding students (36.23). Information on the metaphors of these categories is presented below.

\subsubsection{Category 1. A Course Being an Illuminating Factor (15.22)}

There are 9 metaphors of this category. According to pre-service teachers, teacher profession ethics is an illuminating course. According to the Table 3, the most common metaphors in this category are light (8) and sun (5) metaphors. Some of the direct references to metaphors mentioned in this category are as follows:

"Teacher profession ethics is like light because it illuminates each individual with its knowledge." (S.12)

"Teacher profession ethics is like the sky, because just as we open our horizons when we point our heads at the sky, what we learn in the lesson opens our horizons" (S.18)

"Teacher profession ethics is like the sun because it is similar a light in the profession, in the workplace, in life, in society, in the dark." (S.50)

"Teacher profession ethics is like the moonlight because it illuminates our way when we have to step in the dark" (S.51)

"Teacher profession ethics is like the sun because it rises like the sun and illuminates our way in the profession." (S.62)

\subsubsection{Category 2. A Course Being an Information Source (9.42)}

There are 12 metaphors belonging to this category. According to pre-service teachers, the information resources of teacher professional ethics course are sources that inform and teach. According to Table 3, the most widely used metaphor in this category is library (2). Some of the direct references to metaphors mentioned in this category are as follows: 
"Teacher professional ethics course is like a library because it stores information, learning, and gains in its content with examples." (S.5)

"Teacher professional ethics course is like a library because it covers all the information we should not do or do in the profession " (S.16).

"Teacher professional ethics course is like an hourglass because information is slowly uploaded and eventually learned" (S.17)

"Teacher profession ethics is like writing an article because a student is pen, and information is ink, which is similar to making the correct works with the correct information." (S.86)

\subsubsection{Category 3. A Course Being Personal Development Resource (7.97)}

There are 9 metaphors belonging to this category. According to pre-service teachers, teacher professional ethics course contributes to their personal development. According to Table 3, the most commonly used metaphors in this category are gardener (2) and scales (2) metaphors. The direct references for the metaphors mentioned in this category by pre-service teachers for the teacher professional ethics course are as follows:

"Teacher profession ethics is like hours; because as you live by experiencing, you learn in time" (S.7)

"Teacher profession ethics is like a rose; because if you develop yourself like a rose, you will not fade away"(S.25)

"Teacher profession ethics is like scales; because a person with all the ethical values is a balanced person. It allows us to be balanced "(S.44)

"Teacher professional ethics course is like a gardener; professional ethics course also allows us to be good individuals with its principles by getting knowledge to our mind like a seed " (S.73)

"Teacher profession ethics is like a tree; because when the true place and time comes, if we comply with ethical principles, flowers bloom, give color and the fruit grows. It teaches us to be rooted." (S.79)

\subsubsection{Category 4. An Important Course (17.39)}

There are 23 metaphors belonging to this category for pre-service teachers, Teaching Ethics course is an important lesson. According to Table 3, the most commonly used metaphor in this category is gold (2). The direct references for the metaphors mentioned in this category by pre-service teachers for the teacher professional ethics course are as follows:

"Teacher profession ethics is like a tree of life; because ethical principles are like branches of a tree we need to know for a lifetime. We need to be right to have a healthy root and growth" (S.60)

"Teacher profession ethics is like a gold; because, the importance and value increases as you live, over time" (S.66)

"Teacher profession ethics is like gold; because the information it teaches is very valuable " (S.71)

"Teacher profession ethics is like hour and minute hand; because watch without hour and minute hand won't run. Life is also similar. If there are no ethical rules, it won't run, and there will be difficulties "(S.83)

"Teacher profession ethics is like a key; because it allows us to open doors that are right and ethical in all matters of business, school, family etc. It does not comply with improper behavior, does not open the door "(S.95)

"Teacher profession ethics is like a treasure; because it accommodates valuable principles in it." (S.99)

\subsubsection{Category 5. A Course That Reminds Social Values (4.35)}

There are 5 metaphors belonging to this category. For pre-service teachers, the teacher professional ethics course is a reminder of social values. According to Table 3, the most commonly used metaphor in this category is family (2). The direct references for the metaphors mentioned in this category by pre-service teachers for the teacher professional ethics course are as follows:

"Teacher profession ethics is like a family; because like the education, we take in the family, all values such as morality, love, respect exist in this lesson." (S.48)

"Teacher profession ethics is like a tree; because even its shadow gives you confidence. It is like the trust given by the society with good and proper behavior "(S.78)

"Teacher profession ethics is like a school; because schools teach you to be a useful individual. Teacher professional ethics course teaches us to be a beneficial individual to society. " (S.90)

"The Teacher professional ethics course is like a heart; because the better the heart works, the better the body. The more ethical principles we have in our lives, the healthier society we become. " (S.119) 


\subsubsection{Category 6. A Course Emphasizing Vital Values (2.17)}

There are 3 metaphors belonging to this category. According to the pre-service teachers, the teacher professional ethics course is a necessary course in terms of a vital need, emphasizing vital values. The metaphors used in this category according to Table 3 are water (1), water-air-soil (1) and soil (1). The direct references for the metaphors mentioned in this category by pre-service teachers for the teacher professional ethics course are as follows:

"Teacher profession ethics is like water; because it is one of the basic lessons that need to be learned like the basic needs of life "(S.26)

"Teacher profession ethics is like water; because it's an integral part of our lives that we always need. " (S.89)

\subsubsection{Category 7. A Developing-Forming Lesson (7.25)}

There are 10 metaphors belonging to this category. According to the pre-service teachers, the teacher professional ethics course is a lesson that raises human beings and shapes them in a good way. The metaphors used in this category according to Table 3 are tree (1), mirror (1), flower (1), wave (1), sculptor (1), book (1), carpentry (1), knitting knot (1), chess (1), and pot (1). The direct references for the metaphors mentioned in this category by pre-service teachers for the teacher professional ethics course are as follows:

"Teacher professional ethics course is like pots; because like the food cooked on the stove, students are maturing and ripening with it. Fire is knowledge and teacher. The course is slowly cooked us in the right behavior. " (S.101)

"Teacher professional ethics course is like a sculptor; because similar to the sculptor revealing a new shape, teachers guide us and give the right shape by treating students ethically." (S.109)

"Teacher professional ethics course is like knitting knot; because it is knitted regularly over time. Ethics are also knitted with knot. If a knot is wrong, we must unstitch by repeating all." (S.110)

"Teacher Professional Ethics course is like carpentry; because, as the carpenter shaped the furniture, this course also shaped us to be teacher in accordance with ethical principles." (S.115)

"Teacher Professional Ethics course is like a flower; because it tells the beauties of teaching profession. It prepared us for the future to behave ethically against our students as delicate as flowers and to be sensitive in our behaviors." (S.128)

\subsubsection{Category 8. A course Guiding Students (36.23)}

There are 25 metaphors belonging to this category. For the pre-service teachers, the course of teacher profession ethics is a lesson that shows the true, right direction to individuals. According to Table 3, the most commonly used metaphor for this category is the compass metaphor (9). The following commonly used metaphors are guide (7), map (5), and book (4). The direct references for the metaphors mentioned in this category by pre-service teachers for the teacher professional ethics course are as follows:

"Teacher professional ethics course is like navigation; because it shows the right route for the profession." (S.2)

"Teacher professional ethics course is like a compass; because in the face of any situation, it guides people about the matters like love, justice, tolerance "(S.10)

"Teacher professional ethics course is like a book; because as we read, it gives direction to our behavior, drives to the right path. " (S.11)

"Teacher professional ethics course is like a wind rose; because no matter where the wind blows, it returns persons to the right path in the light of information. " (S.15)

"Teacher professional ethics course is like steering wheel; because it showed that we must go to the right direction." (S.19)

"Teacher professional ethics course is a guide; because it will guide us in our professional lives and guides us wherever we are." (S.23)

"Teacher professional ethics course is like a map; because it helps us to move towards the right path in accordance with the rule" (S.24)

"Teacher professional ethics course is like navigation; because it tells and shows the way we should follow from the day we started the profession to the day of our last mission." (S.34)

"Teacher professional ethics course is like looking at the world sphere; because it is like looking at a different side in each turn. You will see different features. It allows us to make healthy assessments." (S.81)

"Teacher professional ethics course is like a polar star; because it guides us to stop and think about the wrong decisions 
and actions that will lead to the wrong way in teaching and affects the future of the students we raise." (S.118)

Based on the findings, it is observed that pre-service teachers produce positive metaphors related to teacher profession ethics. According the findings based on the categories developed from the metaphors produced by pre-service teachers, it is seen that the teacher professional ethics course is a guide and more pronounced in terms of being an important course.

\section{Discussion}

The desired good and correct behavior defined by ethics is very important, not only in our business life but also in our social life. As in the world, we witness situations in which people who are exposed to unethical behaviors. In this sense, as in all areas of human life, the concept of ethics comes to the fore in teaching profession and educational institutions. This study aims to metaphorically determine the perception of pre-service teachers about teacher profession ethics. According to the results, it was determined that pre-service teachers produced 77 metaphors for the teacher professional ethics course. All of these metaphors have been concluded to be positive metaphors. It was observed that the most common metaphors produced by pre-service teachers were compass and light metaphor according to their frequencies. Then we determined that the guide, sun, book, and map metaphors were expressed more than the other metaphors. These 77 metaphors produced by pre-service teachers were grouped in 8 different categories in terms of their common characteristics. These categories are listed as a course being an illuminating factor, a course being an information resource, a course being personal development resource, an important course, a course emphasizing vital values, a developing-forming lesson and a course guiding students.

According to the other findings obtained from the research, the most used metaphor that is loaded into the teacher professional ethics course is located in the category of "a course guiding students". According to pre-service teachers, the teacher professional ethics course guides people and directs them to the right direction. The most used metaphor in this category is the compass. At this point, the teacher professional ethics course serves as a compass for people to achieve the desired good and the truth. In the guide, book and map metaphors, which are the most mentioned metaphors, the pre-service teachers expressed the course as a guide to the correct behavior. In parallel with these results, in the study of Gökçek (2018), the participants emphasized that the teacher should exhibit attitudes and behaviors to be an example and guide to individuals in all aspects.

Another category in which much metaphor is used is the title of "an important course". They expressed the importance of the course using the concepts such as gold and treasure to express that it is very valuable in social life, and they also used the concepts we use to express vital values such as water, vitamins, and rain as metaphors. According to pre-service teachers, teacher professional ethics course is an important and valuable lesson. In Gökçek's (2018) study, students stated that teaching should have a concept of ethics in teaching to raise a good generation by emphasizing the human raising mission. They mentioned the need for ethics to raise individuals who are useful to society. Pelit and Güçer (2006) also stated that the ethics course should be compulsory for the participants.

Although some of the metaphors that the pre-service teachers produced for the teacher professional ethics course are similar, their motives are also observed to be different. For example, while the sun metaphor is justified by a feature that illuminates, as in the real sense of a pre-service teacher, another pre-service teacher associated the solar metaphor with knowledge, he explained as the enlightenment he created in his own life in accordance with the information he received in the course. In a sense, he produced metaphors within metaphor. In this sense, we also noted that students can express their unique attitude and in-depth thinking powers to expressing their perceptions towards the course.

One of the most fundamental characteristics of teaching profession is that it guides people to be brave enough to behave in accordance with ethical principles and internalize it, reflect in life, and act in this way. It can be said that the perceived perceptions of pre-service teachers towards teacher professional ethics course will have an impact on the future generations. The proposals developed in the light of all these results in the research are as follows:

- This research was conducted with the participation of pre-service teachers who took the course of teacher profession ethics within the scope of pedagogical formation training certificate program, also similar research can be conducted to determine the metaphorical perceptions of the pre-service teachers who study in different branches/departments.

- In-service trainings/seminars on teacher profession ethics can be given to teachers who are already employed in schools, and their metaphorical perceptions may be determined.

- In accordance with the renewed undergraduate program, a similar study can be carried out after the obliged courses of "morals and ethics in education", and research can be carried out to compare metaphorical perceptions, similarities, differences among students studying in different departments/branches. 


\section{References}

Arnett, R. C. (1999). Matephorical Guidance: Administration as Building and Renovation. Journal of Educational Administration, 37(1), 80-89. https://doi.org/10.1108/09578239910253953

Ataünal, A. (2003). Why and How to Teach a Teacher?. The National Education Foundation Publishing.

Ateş, N. (2012). Work Ethics and Values in Teaching. Journal of Education and Humanities, 3(6), 3-18. http://www.ebs.org.tr/ebs_files/files/yayinlarimiz/157-egitimbirsen.org.tr-157.pdf.

Aydın, İ. (2013). Ethics in Education. Ankara: Pegem Publising.

Basic Law of National Education (1973). Retrieved January 07, 2019, from http://www.mevzuat.gov.tr/MevzuatMetin/1.5.1739.pdf

Bogdan, R. C., \& Biklen, S. K. (1998). Qualitative Research for Education: An Introduction to Theory and Methods. (3rd Edition). Boston: Allyn and Bacon.

Boon, H. J. (2011). Raising the Bar: Ethics Education for Quality Teachers. Australian Journal of Teacher Education, 36(7), 103-121. https://doi.org/10.14221/ajte.2011v36n7.2

Brady, L. (2011). Teacher Values and Relationship: Factors in Values Education, Australian Journal of Teacher Education, 36(2), Article 5. https://doi.org/10.14221/ajte.2011v36n2.5

Bullough, Jr. R. V. (2011). 28Ethical and moral matters in teaching and teacher education. Teaching and Teacher Education, 27, 21, https://pdfs.semanticscholar.org/35fd/48c19f89f0562627cbce9068b278aa0cbd86.pdf

Cerit, Y. (2008). Opinions of Teachers, Teachers and Managers on Metaphors Related to Teacher Concept. Turkish Journal of Educational Sciences, 6(4), 693-712. http://dergipark.gov.tr/download/article-file/256303.

Curriculum and Course Contents (2018). Retrieved January 07, 2019, from http://dosya.kmu.edu.tr/formasyon/userfiles/files/Pedagojik_Formasyon_ders_icerikleri.pdf; http://egitim.giresun.edu.tr/fileadmin/user_upload/duyurular/PEDAGOJIK_FORMASYON/2018_formasyon/Form asyon_Ders_Icerikleri.pdf;

http://egitim.sdu.edu.tr/assets/uploads/sites/70/files/pedagojik-formasyon-egitimi-sertifika-programi-ders-icerikleri -ve-amacii-22122015.pdf

Ekici, G., Baş, M., \& Kızılkaya, O. (2017). Determination of Perception Regarding the "Teaching Profession" of Teacher Candidates: A Work of Metaphor Analysis. International Journal of Eurasian Social Sciences, 8(28), CCLXXXVIII-CCCXIII. http://dergipark.gov.tr/download/article-file/146328

Erdem, A. R., \& Şimşek, S. (2013). Evaluation of Teacher Professional Ethics. Adlyaman University Journal of the Institute of Social Sciences, 6(15), 185-202. http://dergipark.gov.tr/download/article-file/15096.

Gökçe, O. (2006). Content Analysis Theoretical and Practical Information. Ankara: Siyasal Publising.

Gökçek, T. (2018). Pedagogic Formation Students' Views on Ethics of Teaching Profession and Their Suggestions. Cukurova University Faculty of Education Journal, 47(2), 710-737. DOI: 10.14812/cuefd.414880.

Haynes, F. (2014). Ethics in Education. İstanbul: Ayrıntı Publising.

HEB-a (Higher Education Board-a) [YÖKa.] (2018). New Regulation on Teaching Undergraduate Programs. Retrieved January 07, 2019, from http://www.yok.gov.tr/ogretmenlik_lisans_yeni_duzenleme

HEB-b (Higher Education Board-b) [YÖKb.] (2018). New Teacher Training Undergraduate Programs. Retrieved January 07, 2019, from http://www.yok.gov.tr/web/guest/icerik/-/journal_content/56_INSTANCE_rEHF8BIsfYRx/10279/41807946

Karataş, A. (2013). Importance of Professional Ethics for Primary School Teacher Candidates. Marmara Journal of Geography, 28 (Temmuz), 304-318. http://dspace.marmara.edu.tr/bitstream/handle/11424/2729/783-1526-1-SM.pdf?sequence=1\&isAllowed=y

Koç, E. S. (2014). Metaphorical Perceptions of Classroom Teacher Candidates about Teacher and Teaching Profession Concepts. Journal of İn̈̈nü University Faculty of Education, 15(1), 47-72. https://doi.org/10.17679/iuefd.79408

Lakoff, G., \& Johnson, M. (2015). Metaphors of Life, Meaning, Language. (Translated G. Y. Demir). İstanbul: İthaki Publisng.

Lester, S. (1999). An Introduction to Phenomenological Research. Taunton UK: Stan Lester Developments. Retrieved February 03, 2019, from www.sld.demon.co.uk/resmethy.pdf

Mayring, P. (2000). Qualitative content analysis. Forum: Qualitative Social Research, 1(2). Retrieved February 03, 
2019, from http://www.qualitative-research.net/index.php/fqs/article/view/1089/2385

Miles, M. B., \& Huberman, A. M. (1994). Qualitative Data Analysis. Thousand Oaks, CA: Sage.

Morgan, G. (1998). Metaphor in Management and Organizational Theories. (Translated: G. Bulut). İstanbul: MESS Publising.

Patton, M. Q. (2014). Qualitative Research and Evaluation Methods. Ankara: Pegem Publising.

Pelit, E. \& Güçer, E. (2006). The Perceptions of Teacher Candidates Concerning Unethical Behaviours about Teaching Profession and Factors Incling Teachers Unethical Behaviour. Journal of Trade and Tourism Education Faculty, 2 , 95-119.

Principles and Procedures for Pedagogical Formation Education Certificate Program. (2014). Retrieved January 07, 2019, from http://www.yok.gov.tr/web/guest/icerik/-/journal_content/56_INSTANCE_rEHF8BIsfYRx/10279/20361248

Schmitt, R. (2005). Systematic Metaphor Analysis as a Method of Qualitative Research. The Qualitative Report, 10(2), 358-394. Retrieved February 03, 2019, from https://nsuworks.nova.edu/tqr/vol10/iss2/10

Tirri, K. (2010). Teacher Values Underlying Professional Ethics. T. Lovat, R. Toomey, N. Clement (Eds.). International Research Handbook on Values Education and Student Wellbeing, p.153-162. Dordrecht: Springer. https://doi.org/10.1007/978-90-481-8675-4_9

Türkeri, M. (2017). Education, Politics, Public, Work Life and Science. İstanbul: Lotus Publising.

Yıldırım, A., \& Şimşek, H. (2013). Qualitative Research Methods in the Social Sciences. Ankara: Seçkin Publising.

Yob, I. M. (2003). Thinking Constructively with Metaphors. Studies in Philosophy and Education, 22(2), 127-138. Retrieved February 03, 2019. https://doi.org/10.1023/A:1022289113443

\section{Copyrights}

Copyright for this article is retained by the author(s), with first publication rights granted to the journal.

This is an open-access article distributed under the terms and conditions of the Creative Commons Attribution license which permits unrestricted use, distribution, and reproduction in any medium, provided the original work is properly cited. 